\title{
Effects of Long-term Cholesterol Diet on Cholesterol Concentration and Development of Atherosclerosis in Homozygous Apolipoprotein E-deficient Mice
}

\author{
D. BOBKOVÁ ${ }^{1}$, Z. TONAR ${ }^{1,2}$ \\ ${ }^{1}$ Laboratory for Atherosclerosis Research, Institute for Clinical and Experimental Medicine, \\ Prague, Czech Republic \\ ${ }^{2}$ Department of Histology and Embryology, Faculty of Medicine in Pilsen, Charles University in Prague, \\ Czech Republic \\ Received May 6, 2005 \\ Accepted November 10, 2005
}

\begin{abstract}
Bobková D., Z. Tonar: Effects of Long-term Cholesterol Diet on Cholesterol Concentration and Development of Atherosclerosis in Homozygous Apolipoprotein E-deficient Mice. Acta Vet. Brno 2005, 74: 501-507.

Homozygous apolipoprotein E-deficient (apo E KO) mice represent a suitable model for the experimental study of atherosclerosis. The aim of our study was to evaluate the relationship between the duration of a cholesterol diet and the development of atherosclerosis. Apo E KO mice were divided into two groups. Group $1(n=8)$ received a cholesterol diet from the first day of life after birth (through the breast milk of the mothers on a cholesterol diet), Group $2(n=6)$ received a control diet (as well as their mothers) for the first 3 months, and a cholesterol diet from the third month of life. The animals were euthanased by decapitation at the age of five months. Blood was used for the measurement of cholesterol concentrations. From a series of 72 histological sections through the descendent thoracic aorta, 8 samples were selected in a uniform systematic random manner and used for a stereological quantification of atherosclerotic lesions.

In comparison with the mice on a cholesterol diet for 2 months (Group 2), the total cholesterol concentration in the mice on a cholesterol diet for 5 months (Group 1) was lower $(31.69 \pm 4.10$ $\mathrm{mmol} / 1$ and $26.75 \pm 3.23 \mathrm{mmol} / 1$, respectively, $p<0.05$ ), and the volume of atherosclerotic lesions was higher $(p<0.04)$.

Although atherosclerotic changes were found in both Groups 1 and 2, we found the atherosclerotic lesions to be significantly more developed in the experimental group fed a cholesterol diet for five months (Group 1) than in the group fed the same diet for two months only (Group 2).

It can be concluded that the lower cholesterolemia found in apo E KO mice after five months of a cholesterol diet (Group 1) compared to the group fed the diet for two months only (Group 2), together with accelerated atherosclerosis is probably due to the combination of an increased excretion of cholesterol from the body via production of bile acids, and increased penetration of cholesterol to the vessel wall.
\end{abstract}

Animal model, histology, cholesterol concentration, morphometric analysis, stereology

Apolipoprotein E (apo E), the ligand of receptors, plays an important role in the lipoprotein metabolism (Reardon et al. 2001; Beisiegel et al. 1989). It has been found that the loss of synthesis of apolipoprotein E in homozygous apolipoprotein E-deficient (apo E KO) mice (Paigen et al. 1994; Smith 1998; van Dijk et al. 1999) is associated with inhibited utilization of residual particles, increased penetration of LDL particles into the vessel wall (Plump et al. 1992; Breslow 1993; Breslow 1996), and the development of atherosclerotic lesions due to the affected cholesterol reverse transport, in which apo E plays a pivotal role (von Eckardstein 1996). Basal cholesterolemia of apo E KO homozygotes is up to five times higher than that of animals of the same strain without the genetic defect, namely about $10 \mathrm{mmol} / \mathrm{l}$. Apo E KO homozygotes are highly sensitive to dietary intervention due to the inability of apo E production. In these animals, administration of 
a cholesterol-containing diet leads to an increase in cholesterolemia and the development of macroscopic atherosclerotic lesions (van Ree et al. 1994).

Stereology-based assessment of 2-D structures allows us to estimate several 3-D parameters, e.g. the volume of the object under study. Recently, the point-counting method proved suitable for histological quantification of atherosclerotic lesions (Nachtigal et al. 2002). This can be done on various microscopic scales in an effective and reproducible way, taking into account the precise calibration of photomicrographs. Practical methods for biological morphometry were reviewed e.g. by How ard and Reed (1998) and Gray (1996). Mout on (2002) gave a comprehensive description of both principles and practices of stereology in biomedical and material research.

The aim of our work was to analyse changes in cholesterol concentrations and to quantify differences in the volume of atherosclerotic lesions in histological sections through the descendent thoracic aortas of apo E KO mice on a cholesterol diet for two and five months, respectively.

\begin{abstract}
Materials and Methods
Animals and diets

Homozygous (-/-) apolipoprotein E-deficient mice (apo E KO mice) (C57B1/6 strain) (n=14) obtained from the Jackson Laboratory in Bar Harbor, Maine (USA) were used. During the experiment, the animals were fed standard laboratory chow (control diet) or a cholesterol diet (control diet containing 5\% fat and 2\% cholesterol). After birth, all animals were divided into two groups: Group $1(\mathrm{n}=8)$ received the cholesterol diet from the first day of life (through the breast milk of mothers on a cholesterol diet), Group $2(n=6)$ received the control diet (as well as their mothers) for the first 3 months, and the cholesterol diet from the third month of life.

At the age of five months, non-fasted animals were sacrificed by a cervical dislocation and their blood (with a small contamination of the lymph) was collected after euthanasia for the analysis of plasma cholesterol concentrations, and their descendent thoracic aortas were used for the analysis of vessel morphology. At the end of the experiment, mean weight of each group of animals was comparable (about $32 \mathrm{~g}$ ).

During the experiment, all animals were kept in cages placed at a conventional breeding place, under standard conditions $\left(21^{\circ} \mathrm{C}, 45 \%\right.$ air humidity, 12 hours daylight) with a water intake ad libitum. The study protocol was approved by the local research ethical committee.
\end{abstract}

\title{
Lipoprotein analysis
}

Plasma was collected by centrifugation of the whole blood (containing $5 \mu \mathrm{l}$ of $10 \%$ EDTA per $1 \mathrm{ml}$ of blood) for $10 \mathrm{~min}$ at $12000 \mathrm{rpm}$. Cholesterol concentrations were measured using colorimetric enzymatic assay kits (Boehringer Mannheim Biochemicals, Germany).

Histology and quantitative analysis

We analyzed samples of the descendent thoracic aorta. After a formalin fixation, segments of the aortas were processed by a common paraffin technique. Each sample was cut into 72 serial sections (thickness of $5 \mu \mathrm{m}$ ) with a transversally oriented cutting plane, and stained with hematoxylin and eosin (HE) and green trichrome modified according to Kočová (1970).

For an immunohistochemical detection of smooth muscle cells, the endogenous peroxidase activity was blocked by a solution composed of hydrogen peroxide (1 volume) and methanol ( 50 volumes). For alpha-smooth muscle actin detection, sections were incubated with a monoclonal mouse anti-human antibody (clone 1A4, dilution 1:150; Dako, CA, USA) for 12 hours at $4{ }^{\circ} \mathrm{C}$. As stated in the manufacturer's declaration, the antibody cross-reacts with the alpha-smooth muscle actin-equivalent protein in the mouse as well. The secondary antibody $\left(45 \mathrm{~min}, 37^{\circ} \mathrm{C}\right)$ and avidin-biotin peroxidase complex $\left(45 \mathrm{~min}, 37^{\circ} \mathrm{C}\right)$ were applied, using the Novostain Super ABC Universal Kit (Novocastra Laboratories Ltd., GB). Following immunohistochemistry, the background tissue was stained with Gill's haematoxylin (30 s; Bio-Optica, Italy).

For a quantitative analysis, we followed the well-documented methodology of Nachtigal et al. (2002, 2004) with respect to general principles of stereology (Howard and Reed 1998). A segment of $0.36 \mathrm{~mm}$ underwent a stereological analysis with the use of the PointGrid module (Plate I, Fig. 2, 3) of the Ellipse software (ViDiTo, Košice, Slovakia). Within the reference volume, eight equidistant sections were selected through systematic uniform random sampling. The position of the first tissue section in the volume was random, i.e. equal to a product of $\left(72^{*} n\right)$, where $n$ was a random number between 0 and 1 . Starting with this section, every ninth section was captured with two constant magnifications, so that the distance between the two neighbouring calibrated photomicrographs (sampling period) was $45 \mu \mathrm{m}$. We assessed the area of an atherosclerotic lesion in each tissue section according to Equation 1: est $A=a \times P$, 
where est $A$ is the estimated area, grid parameter $a$ is the area corresponding to one test point and $P$ is the number of test points hitting the atherosclerotic lesion. The Cavalieri principle (Rus s and Dehoff 2001) was used for the estimation of the volume $V$ of the atherosclerotic lesion within the reference segment of the aorta, see Equation 2:

$$
\text { est } V=T *\left(A_{1}+A_{2}+\ldots+A m\right)
$$

where est $V$ is the Cavalieri volume estimator, $T=0.045 \mathrm{~mm}$ is the distance between the two following selected sections, and $A_{i}$ is the area of the atherosclerotic lesion in the $i$-th section. We evaluated eight sections as representatives of each tissue sample, i.e. $(m=8)$.

The area fraction of the free vessel lumen (AFFVL) was used as a parameter that characterizes the relative obliteration of the aortic lumen by the atherosclerotic lesion, see Equation 3:

$$
\text { AFFVL }=\left[\left(1-\frac{\text { A(lesion) }}{\text { A(lumen })}\right)\right] * 100 \%,
$$

where A(lesion) is the area of the atherosclerotic lesion, and A(lumen) is the area of the total vessel lumen, including the lesion. In the case of a deeper invasion of the lesion towards tunica media, where the border between subendothelial connective tissue and tunica media was altered, the arbitrary bottom of the atherosclerotic lesion was considered to be at the level of the innermost elastic lamina. We compared our findings to the classification of atherosclerotic lesions recommended by the American Heart Association (Stary et al. 1994, 1995; Stary 2000). In the lesion type I, isolated macrophage foam cells invade the intima. Multiple foam cell layers are formed in the lesion type II. Isolated extracellular lipids pools are added in type III. In type IV, confluent extracellular lipid pools are formed. Further progression leads to the production of fibromuscular tissue layers (type V). Surface defects, haematoma, and thrombosis represent type VI lesions, which are very rare in the mouse aorta. Calcification or fibrous tissue changes predominate in lesion types VII, or VIII, respectively.

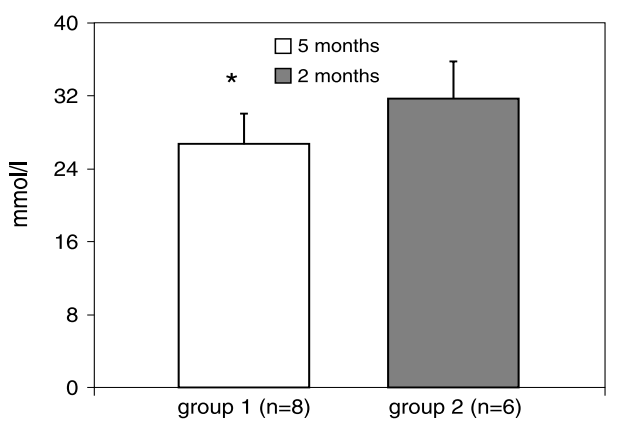

Fig. 1. Cholesterol concentrations in plasma in apo E KO mice after a cholesterol diet.

${ }^{*} p<0.05$ vs. two months, $\mathrm{n}=$ number of animals

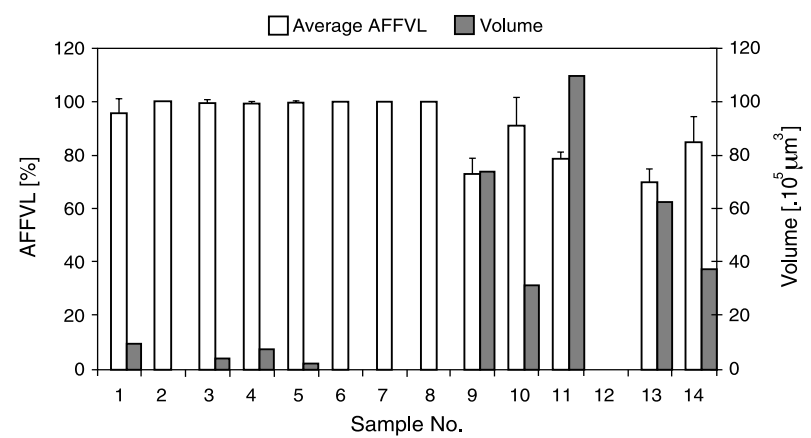

Fig. 4. The average area fraction of the free vessel lumen in one histological section (AFFVL, mean \pm SD) and estimated total volume of atherosclerotic lesion in the reference volume. The AFFVL is highly inversely correlated with the volume $(r=-0.89)$. The sample No. 12 was deleted because of mechanical damage. 
Statistics

The unpaired Student's $t$-test was used to test for differences between the groups. Data are presented as means \pm SD. The Welch test was used to compare the stereological parameters estimated in the animal group under study. In both cases, the differences are considered statistically significant if $p<0.05$. The correlation was assessed with the use of the Pearson correlation coefficient.

\section{Results}

The resulting cholesterol concentrations in apo $\mathrm{E} \mathrm{KO}$ mice after two or five months on a cholesterol diet are summarized in Fig. 1. In both Groups 1 and 2, total cholesterolemia was higher than had been found in previous studies in the apo E KO mice on chow. Plump et al. (1992) and also Breslow (1993) described in their experiments the plasma cholesterol concentrations in apo E KO mice on chow (control diet) as being about $10 \mathrm{mmol} / \mathrm{l}$. Total cholesterol concentrations in the mice on the cholesterol diet for a period of five months (Group 1) was lower in comparison with the mice after two months on a cholesterol diet (Group 2). The differences between the groups were about $5 \mathrm{mmol} / \mathrm{l}$.

The quantitative results are summarized in Fig. 4. Average area fraction of a free vessel lumen in one histological section was found to be lower in Group $2(p=0.030)$ and the estimated total volume of atherosclerotic lesions was higher $(p=0.037)$ in the reference volume of animals of Group 2, when compared to Group 1. The AFFVL values were highly inversely correlated with the volume of lesions $(r=-0.89)$. The sample No. 12 was deleted because of mechanical damage.

Table 1. Presence (+) or absence (-) of intact (i.e. atherosclerosis-free) segments, atherosclerotic plaques and branching in the reference volume of thoracic descendent aortas. The extent of atherosclerotic plaques is indicated semiquantitatively according to subjective evaluation. The sample No. 12 was deleted (o) because of mechanical damage.

\begin{tabular}{|c|c|c|c|}
\hline Sample No. & Intact segment & Atherosclerotic plaque & Branching \\
\hline 1 & + & + & + \\
2 & + & - & - \\
3 & + & + & + \\
4 & + & + & + \\
5 & + & + & + \\
6 & + & - & - \\
7 & + & - & - \\
8 & + & - & - \\
9 & - & ++ & + \\
10 & + & ++ & - \\
11 & - & ++ & + \\
12 & 0 & 0 & 0 \\
13 & - & ++ & + \\
14 & + & + & - \\
\hline
\end{tabular}

Segments of normal and atherosclerotic aortas were observed in both experimental groups, as presented in Table 1. Lesions were situated in the regions of arterial branching (Plate II, Fig. 5, 6, and Plate III, Fig. 7). They expanded beyond the vessel wall and invaded the lumen as bulge-shaped lesions (Fig. 8). No eccentric (non-diffuse) intimal thickening was found. In both groups under study, we found lesions with isolated lipid droplet-laden macrophages (foam cells) and with monocytes adhering to the surface of the endothelium (Fig. 5). This type was comparable to human type I, and it prevailed in Group 1. In Group 2, lesions comparable to type II and III prevailed, the former containing macrophage foam cells accumulated and stratified in adjacent cell layers together. The lipid-laden smooth 
muscle cells were sporadic. Type III-like intermediate lesions (preatheroma) were present in samples No. 5-7, and 9 only (Fig. 6, 7, and Plate IV, Fig. 8). In these samples, small extracellular lipid deposits and cell remains formed isolated pools below the foam cell layers. Underneath the lesion, the interlamellar distance between the neighbouring elastic membranes was found to have increased. The accumulations of macrophages and extracellular lipids were separated by smooth muscle cells (Fig. 9).

\section{Discussion}

In accordance with our expectations, we found increased cholesterolemia in mice on the cholesterol diet, compared to previous findings on animals on a control diet (Plump et al. 1992; Breslow 1993). It has been found that the loss of a functional allele of the apolipoprotein $\mathrm{E}$ gene in apo $\mathrm{E} \mathrm{KO}$ mice is connected with the inability to maintain cholesterol concentration consistent with that observed in wild-type mice (van Dijk et al. 1999). Loading the lipoprotein metabolisms of these mice by feeding them the cholesterol diet obviously led to a subsequent increase in cholesterolemia and facilitated penetration to the vessel wall and macrophages via their scavenger receptors without a feedback regulation (Plump et al. 1992). Under regular conditions, the vessel wall eliminates a surplus of cholesterol caused by production of HDL lipoproteins rich in apolipoprotein E, via a cholesterol reverse transport from macrophages (von Eckardstein 1996). Because of the loss of synthesis of apolipoprotein E, this way of cholesterol elimination from the vessel is impaired and the accumulation of cholesterol leads to the development of atherosclerosis.

However, we found unexpectedly lower cholesterol concentrations in the mice fed the cholesterol diet for five months, in comparison with the mice after two months on the cholesterol diet. The plasma total cholesterol concentration is known to result from many factors, such as the alimentary cholesterol intake, its synthesis in the body, or its secretion via bile acids (Carey and Hernell 1992). Especially in rodents, a high cholesterol intake from a diet leads to stimulation of cholesterol conversion to bile acids in the liver (Peet et al. 1998). This mechanism was found as a regulator of the total cholesterol concentration in blood. We suppose that the long-term cholesterol feeding led in apo E KO mice to an increase of bile acids production in the liver and their excretion into the intestine. This mechanism together with increased penetration of lipoprotein particles into the vessel wall seems to be the main reason of the decrease of the cholesterol concentration in plasma observed in the apo E KO mice after five months on the cholesterol diet.

The AFFVL parameters and the estimated volume (est $\mathrm{V}$ ) of atherosclerotic lesions are to be considered complementary. The AFFVL parameter is relatively robust with respect to the deviation of the section plane with regard to the transversal plane. In spite of a careful orientation of the paraffin-embedded tissue sample, such a deviation might occur. As AFFVL is a dimensionless ratio, it does not get biased by absolute differences in the size or shape of the aorta among the animals. It was used as a measure of obstruction of the lumen by the lesion. Taking into account the size of the reference volume, it becomes apparent that in most cases we assessed the size of one lesion rather than several lesions. According to our experience, stereological assessment proved accurate, correct and reproducible, having a low intra- and inter-observer variability. If the bias of the results caused by the irregular shape of the lesion were avoided, the total number of test points hitting the area of interest should be above 60 . This number was estimated according to the nomogram of Gundersen and Jensen (1987), taking into account the irregular shape of the lesion and the coefficient of error of the estimate lower than 0.05 . In our method, this conventional limit was certainly exceeded, ranging from 1300 to 3000 (depending on both lumen and lesion shape and size).

The quantitative results are in concordance with the subjective assessment of the samples. An exception appeared in samples No. 7 and 8, where no lesions were found. We assume 
that this happened due to an accidental absence of branching in the aortic segment under study. This explanation is supported by a remarkable coincidence of lesions and branching sites (Table 1). The sites of a lesion disposition are determined in part by haemodynamic forces acting on the endothelial cells. In the regions of arterial branching or curvature, the flow is disturbed. The fluid shear stress increases endothelium permeability to macromolecules, so that these regions become preferential sites for lesion formation ( L u s is 2000).

We conclude that besides a qualitative description, we quantified the volume of atherosclerotic lesions in histological sections through the descendent thoracic aortas of apo E KO mice. This parameter was inversely correlated with the area fraction of the free vessel lumen. We proved that atherosclerotic lesions were significantly more developed in the experimental Group 1 (five months on the cholesterol diet) than in Group 2 (two months on the cholesterol diet).

We assume that the lower cholesterolemia found in apo E KO mice of Group 1 compared to Group 2, together with accelerated atherosclerosis is probably due to the combination of increased cholesterol elimination from the body via bile acids production, and increased penetration of cholesterol to the vessel wall.

\section{Efekt dlouhodobého podávání cholesterolové diety na rozvoj aterosklerotických změn u apolipoprotein E-deficientních myší}

Jeden z nejpoužívanějších experimentálních modelů umožňujících studium rozvoje aterosklerotického procesu představují apolipoprotein E-deficientní (apo E KO) myši. Cílem této studie bylo analyzovat závislost rozsahu aterosklerotického poškození u apo KO myší na délce dietní intervence. Skupina apo E KO myší byla rozdělena do dvou skupin. První skupina byla od prvního dne od narození (prostřednictvím diety matek) živena $2 \%$ cholesterolovou dietou $(\mathrm{n}=8)$, druhá skupina dostávala stejnou cholesterolem obohacenou dietu až od 3. měsíce věku $(n=6)$. Po skončení dietní intervence ( 5 . měsíc věku) byla zvířata dekapitována. Vzorky krve byly použity pro analýzu koncentrace cholesterolu. Rozsah aterosklerotického poškození úseků descendentních hrudních aort byl kvantifikován stereologickým vyhodnocením nestranně systematicky náhodně vybraných vzorků ze série 72 histologických řezů.

U zvířat živených po dobu 5 měsíců cholesterolovou dietou byla nalezena nižší koncentrace $(p<0,05)$ cholesterolu $(26,75 \pm 3,23 \mathrm{mmol} / \mathrm{l})$ v porovnání se zvíraty živenými cholesterolovou dietou po dobu 2 měsíců $(31,69 \pm 4,10 \mathrm{mmol} / \mathrm{l})$. U první skupiny byl objem aterosklerotických lézí signifikantně vyšší $(p<0,04)$.

Paralelně v obou skupinách zviŕrat byly nalezeny na úsecích hrudních aort rozsáhlé aterosklerotické léze, lokalizované zejména do oblastí odstupu větví hrudní aorty. U zvířat živených cholesterolovou dietou po dobu 5 měsíců měla tato ložiska větší rozsah nežli u zviŕat živených cholesterolovou dietou po dobu 2 měsíců.

Z výsledků vyplývá, že dlouhodobé podávání cholesterolové diety je u apo E KO myší spojeno s masivnějším rozvojem aterosklerotických změn v důsledku akcelerovaného ukládání cholesterolu do cévní stěny a pravděpodobně se zvýšením exkrece cholesterolu cestou žlučových kyselin.

\section{Acknowledgements}

This work was supported by the grant 1M6798582302 awarded by the Ministry of Education, Youth and Sports of the Czech Republic. We express special thanks to Mrs. Jaroslava Beránková for her technical assistance.

\section{References}

BEISIEGEL U, WEBER W, IHRKE G, HERZ J, STANLEY KK 1989: The LDL-receptor-related protein, LRP, is an apolipoprotein E-binding protein. Nature 341: 162-164 
BRESLOW JL 1993: Transgenic mouse model of lipoprotein metabolism and atherosclerosis. Proc Natl Acad Sci USA 90: 8314-8318

BRESLOW JL 1996: Mouse models of atherosclerosis. Science 272: 685-688

CAREY, MC, HERNELL, O 1992: Digestion and absorption of fat. Sem Gastrointest Dis 3:189-208

GRAY, T 1996: Quantitation in histopathology. In: BANCROFT, JD, STEVENS, A (Eds): Theory and practice of histological techniques. Churchill Livingstone, New York, pp. 641-671

GUNDERSEN, HJG, JENSEN, EB 1987: The efficiency of systematic sampling in stereology and its prediction. J Microsc 147: 229-263

HOWARD, CV, REED, MG 1998: Unbiased Stereology: Three Dimensional Measurement in Microscopy. Royal Microscopical Society, Microscopy Handbook Series No. 41. Springer-Verlag, New York, 246 p.

KOČOVÁ, J 1970: Overall staining of connective tissue and the muscular layer of vessels. Folia Morphol 3: 293-295

MOUTON, PR 2002: Principles and Practices of Unbiased Stereology. An Introduction for Bioscientists. The Johns Hopkins University Press, Baltimore, 214 p.

LUSIS, AJ 2000: Atherosclerosis. Nature 407: 233-241

NACHTIGAL, P, SEMECKÝ, V, GOJOVÁ, A, KOPECKÝ, M, BENEŠ, V, JŮZKOVÁ, R 2002: The application of stereological methods for the quantitative analysis of the atherosclerotic lesions in rabbits. Image Anal Stereol 21: 165-174

NACHTIGAL, P, SEMECKY, V, KOPECKY, M, GOJOVA, A, SOLICHOVA, D, ZDANSKY, P, ZADAK, Z 2004: Application of stereological methods for the quantification of VCAM-1and ICAM-1 expression in early stages of rabbit atherosclerosis. Pathol Res Pract 200: 219-229

PAIGEN, B, PLUMP, AS, RUBIN, EM 1994: The mouse as a model for human cardiovascular disease and hyperlipidemia. Curr Opin Lipidol 5: 258-264

PEET, DJ, TURLEY, SD, MA, W, JANOWSKI, BA, LOBACCARO, JM, HAMMER, RE, MANGELSDORF, DJ 1998: Cholesterol and bile acid metabolism are impaired in mice lacking the nuclear oxysterol receptor LXR alpha. Cell 93: 693-704

PLUMP, AS, SMITH, JD, HAYEK, T, AALTO-SETALA, K, WALSH, A, VERSTUYFT, JG, RUBIN, EM, BRESLOW, JL 1992: Severe hypercholesterolemia and atherosclerosis in apolipoprotein E-deficient mice created by homologous recombination in ES cells. Cell 71: 343-353

REARDON CA, GETZ GS 2001: Mouse models of atherosclerosis. Curr Opin Lipidol 12: 167-173

RUSS JC, DEHOFF RT 2001: Practical Stereology. 2nd Ed. Plenum Press, New York, 307 p.

SMITH, JD 1998: Mouse models of atherosclerosis. Lab Anim Sci 48: 573-579

STARY HC, CHANDLER AB, GLAGOV S, GUYTON JR, INSULL W JR, ROSENFELD ME, SCHAFFER SA, SCHWARTZ CJ, WAGNER WD, WISSLER RW 1994: A Definition of Initial, Fatty Streak, and Intermediate Lesions of Atherosclerosis: A Report From the Committee on Vascular Lesions of the Council on Arteriosclerosis, American Heart Association. Circulation 89: 2462-2478

STARY HC, CHANDLER AB, DINSMORE RE, FUSTER V, GLAGOV S, INSULL W JR, ROSENFELD ME, SCHWARTZ CJ, WAGNER WD, WISSLER RW 1995: A Definition of Advanced Types of Atherosclerotic Lesions and a Histological Classification of Atherosclerosis. A Report From the Committee on Vascular Lesions of the Council on Arteriosclerosis, American Heart Association. Arterioscler Thromb Vasc Biol 15: 1512-1531

STARY HC 2000: Natural History and Histological Classification of Atherosclerotic Lesions. An Update. Arterioscler Thromb Vasc Biol 20: 1177-1178

VAN DIJK KW, HOFKER MH, HAVEKES LM 1999: Dissection of the complex role of apolipoprotein E in Lipoprotein Metabolism and Atherosclerosis Using Mouse Models. Curr Atherosclerosis Reports 1: 101-107

VAN REE JH, van den BROEK WJ, DAHLMANS VE, GROOT PH, VIDGEON-HART M, FRANTS RR, WIERINGA B, HAVEKES LM, HOFKER MH 1994: Diet-induced hypercholesterolemia and atherosclerosis in heterozygous apolipoprotein E-deficient mice. Atherosclerosis 111: 25-37

VON ECKARDSTEIN A 1996: Cholesterol efflux from macrophages and other cells. Curr Opin Lipidol 7: 308-319 

Plate I

Bobková D. . et al.: Effect of Long-Term ... pp. 501-507

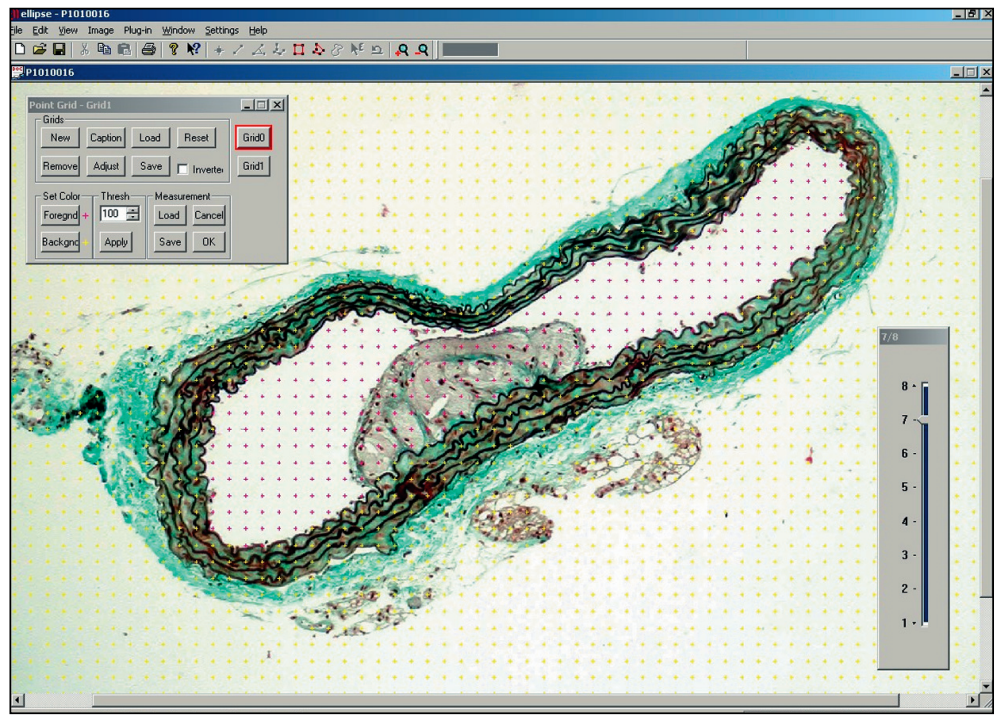

Fig. 2. The estimation of the total area of the aortic lumen was the first step of the AFFVL parameter assessment. The test points hitting the lumen were highlighted (violet). Green trichrome and Verhoeff hematoxylin staining.

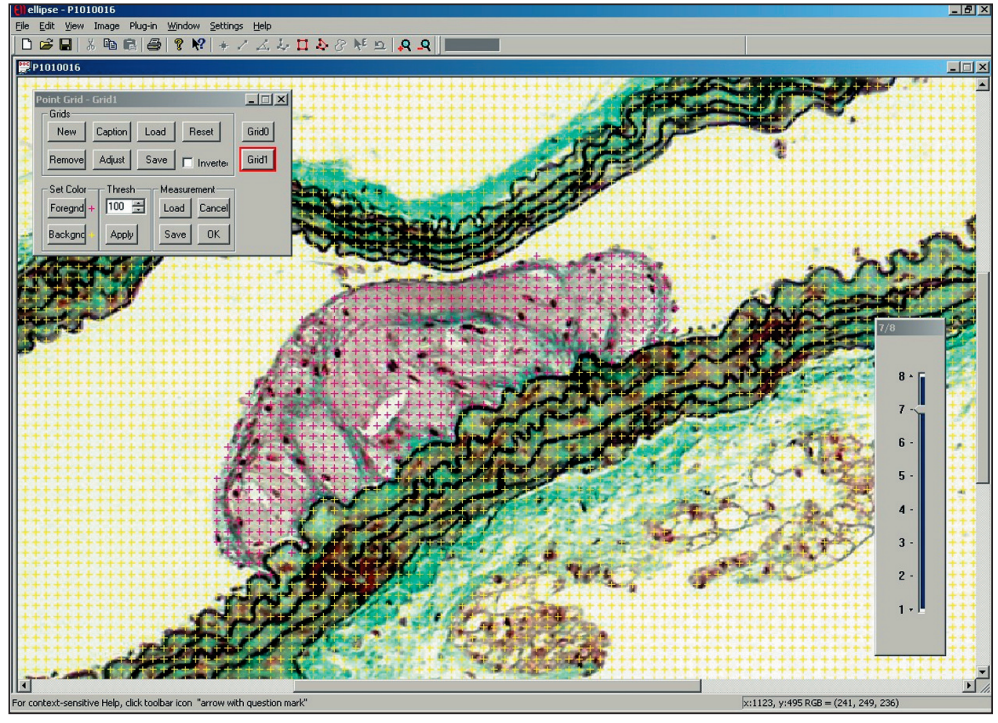

Fig. 3. As a second step of AFFVL assessment, we estimated the lesion area with the use of a highdensity grid of test points. Detail of Fig. 1. 


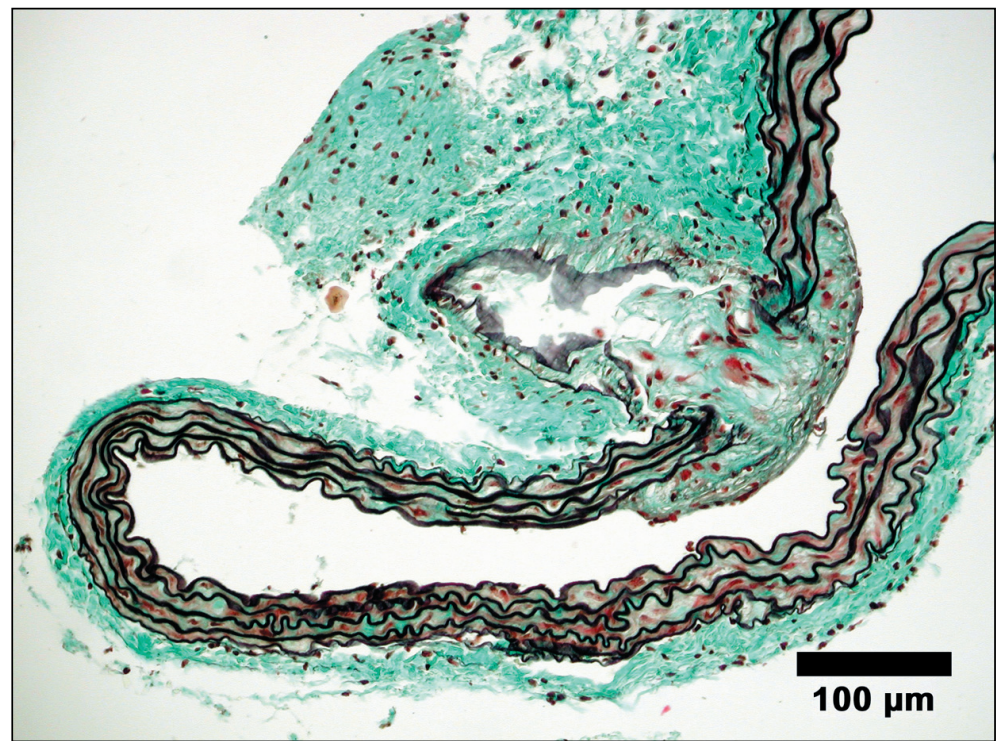

Fig. 5. Sample No. 1 (Group 1). A lesion comparable to human type II contains macrophages covered by a fibrous cap. The branching of the aorta becomes obliterated.

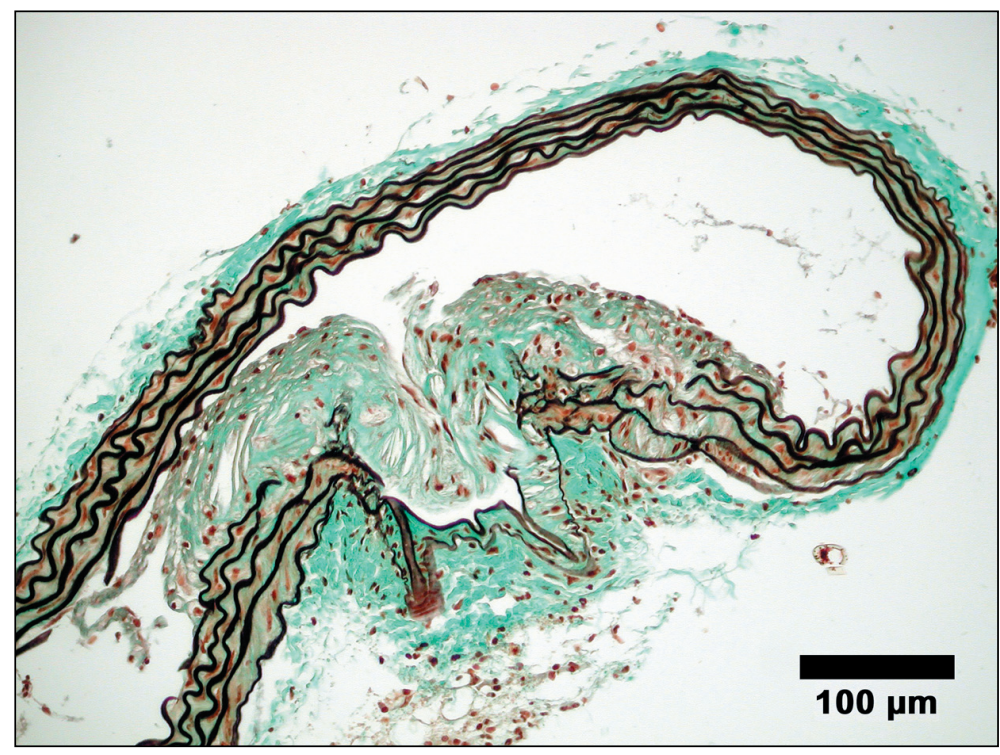

Fig. 6. Sample No. 9 (Group 2). The branching site is occupied by a lesion comparable to human type III which includes extracellular lipids. Note the acicular shape of the empty spaces occupied initially by cholesterol crystals. The superficial elastic laminae are destroyed, and the deeper ones have a dilated interlamellar space filled with lipid-laden smooth muscle cells. 


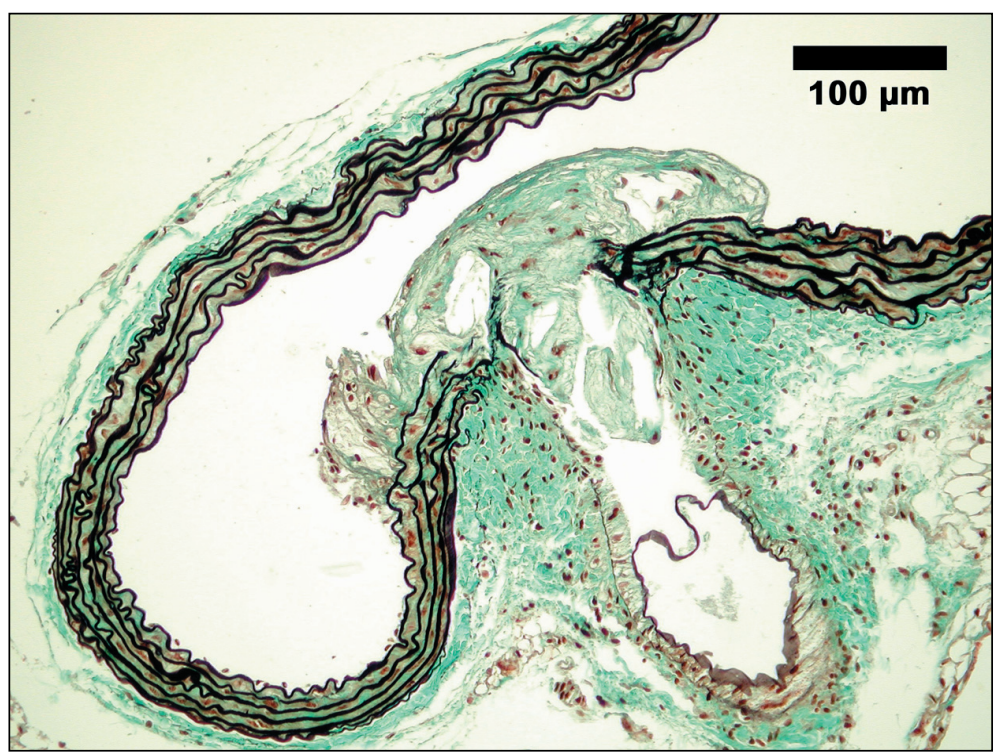

Fig. 7. Sample No. 11 (Group 2). The branching site is occupied by a type III-like lesion with both intra- and extracellular lipid pool.

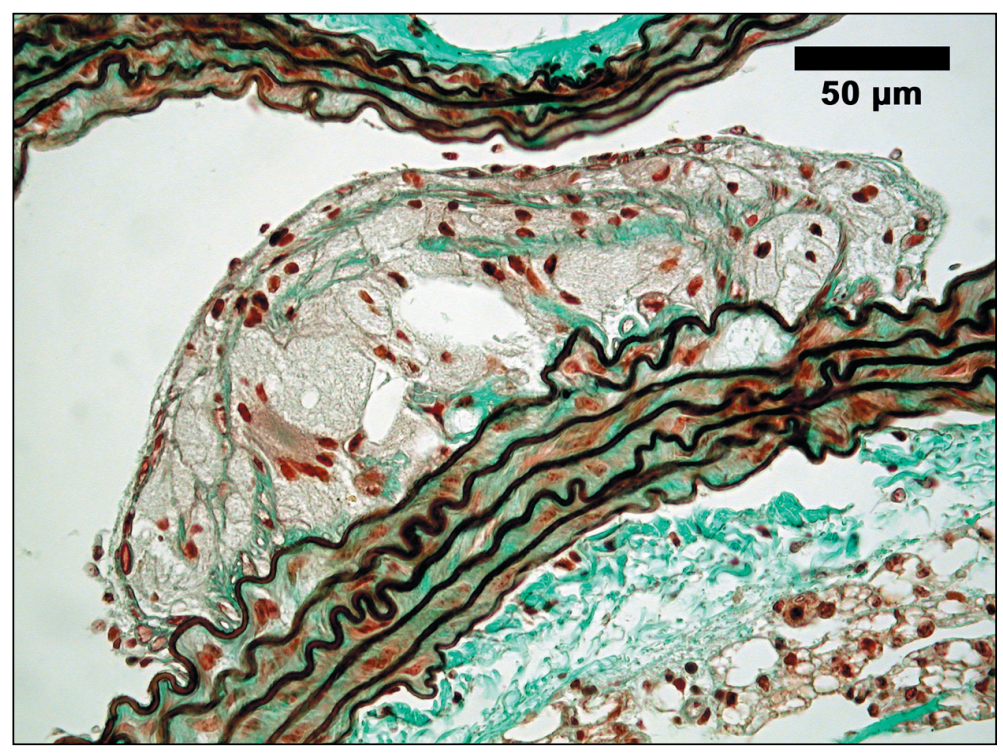

Fig. 8. Sample No. 10 (Group 2). A detailed view of a lesion type analogous to human type III, bulging into the aortic lumen. It contains foam cells as well as extracellular lipid mass and cell debris. Monocytes adhere to the endothelium. 


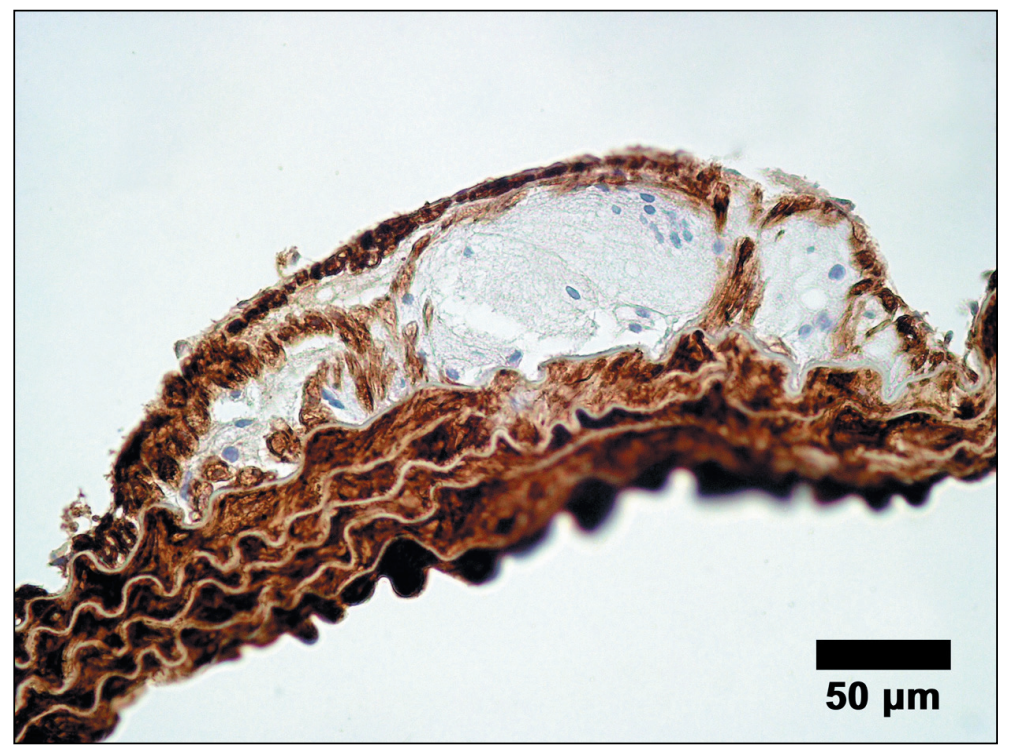

Fig. 9. Sample No. 10 (Group 2): The distribution of alpha-smooth muscle actin within a lesion analogous to human type III. Smooth muscle cells (brown) encircle macrophages and a well delineated accumulation of extracellular lipid (lipid core). 